\title{
Arthropathia ochronotica
}

\author{
Damir Matokovići ${ }^{1,2}$, Mihovil Plečko ${ }^{3}$, Krešimir Crnogaća ${ }^{3}$, Nika Šlaus ${ }^{4}$, Boris Žulj ${ }^{5}$, \\ Marko Pećina ${ }^{4}$ \\ 1. School of Medicine University J.J. Strossmayer, Osijek, Croatia \\ 2. County General Hospital Požega, Požega, Croatia \\ 3. Department of Orthopaedic Surgery, University Hospital Centre Zagreb, Zagreb, Croatia \\ 4. School of Medicine, University of Zagreb, Zagreb, Croatia \\ 5. Clinic for Orthopaedics and Trauma, University Hospital Centre Osijek, Osijek, Croatia
}

OPEN ACCESS

Correspondence: Mihovil Plečko, MD mplecko@kbc-zagreb.hr orcid.org/0000-0001-6569-9287

This article was submitted to RAD CASA - Medical Sciences as the original article

Conflict of Interest Statement: The authors declare that the research was conducted in the absence of any commercial or financial relationships that could be construed as a potential conflict of interest.

Received: 3 November 2020 Accepted: 17 November 2020 Published: 28 December 2020

Citation:

Matoković D, Plečko M, Crnogaća K, Šlaus N, Žulj B, Pećina M. Arthropathia ochronotica

RAD CASA - Medical Sciences. $544=52-53$ (2020): 56-62 DOI: https://dx.doi.org/10.21857/ yvjrdcl4ey

Copyright (C) 2020 Matoković D, Plečko M, Crnogaća K, Šlaus N, Žulj

$\mathrm{B}$, Pećina M. This is an open-access article distributed under the terms of the Creative Commons Attribution License (CC BY). The use, distribution or reproduction in other forums is permitted, provided the original author(s) and the copyright owners(s) are credited and that the original publication in this journal is cited, in accordance whit accepted adacemic practice. No

use, distribution or reproduction is permitted which does not comply with these terms.

\section{ABSTRACT:}

Alkaptonuria (AKU) is a rare autosomal recessive metabolic disease caused by a disorder of phenylalanine and tyrosine metabolism, resulting in accumulation and deposition of homogentisic acid (HGA) in the body. This deposition further causes progressive functional disorders in different organ systems, with the locomotor system being the most affected one. A specific triad of symptoms occurs in patients suffering from AKU: 1. at birth, a change of urine color is present when urine is exposed to air, 2. occurrence of dark pigmentations in connective tissues becomes visible over time, 3. complications of the locomotor, urogenital and cardiovascular systems present gradually.

Arthropathia ochronotica occurs in patients suffering from AKU due to precipitation and deposition of HGA in the joint tissue (cartilage, tendons, ligaments, menisci, etc.). The accumulation can be seen as small foci of blue-black pigmentations. HGA deposits in collagen fibers, causing tendons and ligaments thickening. This causes them to be less resistant to mechanical forces, resulting in frequent ruptures caused by minimal trauma. Also, the deposition facilitates cartilage degeneration, often requiring an operative treatment. The knees are the most commonly affected joints, while changes can be seen in the spine and other large joints.

As there is no specific treatment, alleviation of symptoms is the only treatment option. It has the goal of increasing individual functionality and quality of life. As an option for end-stage treatment, joint replacement surgery proved to be effective. In the future, an enzyme replacement therapy or gene therapy may be developed to treat AKU successfully.

KEYWORDS: alkaptonuria; ochronosis; joint diseases; diagnostic imaging; therapeutics;

\section{SAŽETAK:}

ARTropatija OHRONOTIKA

Alkaptonurija (AKU) je rijetka autosomno recesivna metabolička bolest uzrokovana poremećajem metabolizma fenilalanina i tirozina, što rezultira nakupljanjem i taloženjem homogentizinske kiseline (HGA) u tijelu. Ovo taloženje uzrokuje progresivne funkcionalne poremećaje u različitim organskim sustavima, pri čemu je najčešće zahvaćen lokomotorni sustav. Specifična trijada simptoma javlja se u bolesnika koji pate od AKU: 1. pri rođenju je vidljiva promjena boje urina kada je urin izložen zraku, 2. pojava tamnih pigmentacija u vezivnom tkivu $s$ vremenom postaje vidljiva, 3. postepeno se razvijaju komplikacije koje zahvaćaju lokomotorni, urogenitalni i kardiovaskularni sustav.

Artropatija ohronotica javlja se u bolesnika koji pate od AKU zbog taloženja HGA u zglobnom tkivu (hrskavica, tetive, ligamenti, meniskusi itd.). Akumulacija se može vidjeti kao mala žarišta plavo-crnih pigmentacija. HGA se taloži u kolagenskim vlaknima, uzrokujući zadebljanje tetiva i ligamenata. Zbog toga su ona manje otporna na mehaničke sile, što rezultira čestim puknućima uzrokovanim minimalnom traumom. Također, taloženje ubrzava degeneraciju hrskavice, što dovodi do češće potrebe 
za operativnim liječenjem. Koljena su najčešće zahvaćena, dok se promjene također mogu vidjeti na kralježnici i drugim velikim zglobovima.

Kako ne postoji specifično liječenje, ublažavanje simptoma jedina je opcija liječenja. Cilj mu je povećati individualnu funkcionalnost i kvalitetu života. Kao opcija za završnu fazu liječenja, ugradnja umjetnih zglobova pokazala se sigurnom i učinkovitom. U budućnosti se očekuje razvoj enzimske ili genske terapije za uspješno ciljano liječenje AKU.

KLJUČNE RIJEČI: alkaptonurija; ohronoza; bolesti zglobova; dijagnostika; terapija;

\section{INTRODUCTION}

Alkaptonuria (AKU) is a rare autosomal recessive metabolic disease caused by disorder of phenylalanine and tyrosine metabolism, resulting in the accumulation of homogentisic acid (HGA). It is caused by mutations in the homogentisate 1,2-dioxygenase gene $(H G D)$ on chromosome $3 \mathrm{q} 13.33^{1-3}$. The $H G D$ gene consists of 14 exons and spans 54.363 bp which code for HGD hexamer protein. Many different variants of the $H G D$ have been reported, of which majority represent missense mutations ${ }^{4}$. All variants are summarized in the $H G D$ mutation database (http:// hgddatabase.cvtisr.sk/). The incidence of AKU is estimated at $1: 250000$ to $1: 1000000^{5}$. However, the incidence varies greatly between countries, with an estimated incidence at 1:19 000 in countries such as Slovakia and the Dominican Republic 6-8. Signs of AKU were first described on Egyptian mummies (Harwa) dating from around 3500 years ago. In 1584, Scribonius described a case of a young male patient whose urine became dark when it was exposed to air. In 1866, Virchow described that he found yellow and brown pigmentation of intervertebral discs, larynx cartilage, bronchi cartilage, menisci, articular cartilage, and atherosclerotic plaques in blood vessels while performing an autopsy of a 67-year-old male. He named the condition "ochronosis" ("the yellow disease") ${ }^{9-11}$. The term „alkapton“"was first used by Boedeker in 1859, by which he described a lower level of HGA excretion from the body. In 1908, Garrod suggested that AKU is a hereditary metabolic disease, while Neubauer described the pathological disorder of tyrosine metabolism in $1909^{12}$. In some cases, AKU may present as an arthropathy, called arthropathia ochronotica. Arthropathy is defined as a pathological change of a joint that can be caused by many different etiologies. These changes are characterized by the destruction of cartilage and subchondral bone, which may result in deformation of the joint with subsequent instability, joint contracture, reactive hypertrophy of the synovial tissue, precipitation and deposition of substances in the joint, as well as with the formation of intra-articular loose bodies ${ }^{13}$. They might be caused by impaired innervation (central or peripheral nervous system injuries), inadequate vascularization, bleeding into the joint due to coagulopathies (hemophilia A and B), endocrine disorders, metabolic disorders, connective tissue diseases etc. Arthropathies should be distinct from inflammatory and degenerative diseases of joints. However, it can often be found in the literature that inflammatory diseases are described as arthropathies, i.e. psoriatic arthropathy/psoriatic arthritis. The deposition of certain substances into the joint tissue is a characteristic of metabolic arthropathies ${ }^{14}$. Arthropathia ochronotica is a result of precipitation and deposition of HGA in the joint tissue (cartilage, tendons, ligaments, menisci, etc.). Ochronotic degenerative changes of the knee occur in $64 \%$ of patients between the age of 40 and $50{ }^{15}$. However, changes were also noticed in older patients ${ }^{16}$. Changes of shoulders are present in $43 \%$ of patients, while hips and sacroiliac joints are affected in $35 \%$ of patients ${ }^{15}$. A study of 58 patients suffering from AKU reports on 29 joint replacement surgeries performed in this patients, with $50 \%$ of them undergoing at least one joint replacement surgery by the age of 55 years ${ }^{17}$.

\section{PATHOPHYSIOLOGY AND PATHOLOGY}

Patients suffering from AKU lack an enzyme needed for HGA oxidation in the liver, which causes its insufficient renal excretion and accumulation in the body ${ }^{1,7}$. (Figure 1.) The excessive amount of HGA in the body is excreted into urine. A characteristic sign of AKU is that the urine becomes dark due to oxidation when exposed to air. At a younger age, the deposition of HGA is slower because the excretion by kidneys is more efficient, so the usual onset of symptoms is in the third or fourth decade of life ${ }^{18}$. As HGA accumulates in the body, it deposits in collagen fibers ${ }^{19}$. This deposition causes progressive functional disorders in different organ systems, with the locomotor system being the most affected one ${ }^{20}$. The accumulation can be seen as small foci of blue-black pigmentations most commonly in hyaline cartilage, synovial tissue, and intervertebral discs. (Figure 2.) The deposition of HGA facilitates cartilage degeneration, often requiring an operative treatment such as joint replacement. (Figure 3.) Articular cartilage is mostly affected on the weight-bearing surface, in contrast to inflammatory arthritis, where the loss of joint space is symmetrical on all parts of the joint surfaces ${ }^{21}$. 
Phenylalanine

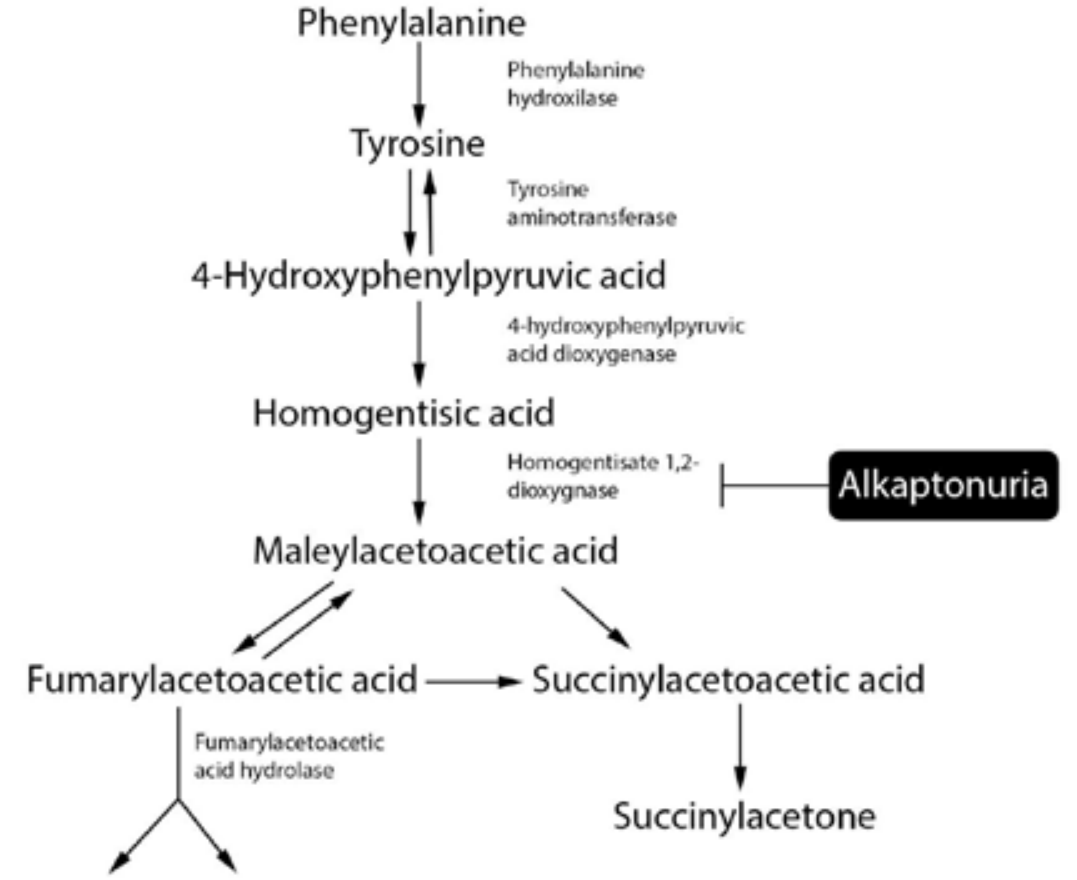

Fumaric acid Acetoacetic acid

Figure 1. Metabolic path of phenylalanine and tyrosine degradation in the body. Alkaptonuria is a genetic disease affecting the activity of homogentisate 1,2-dioxygenase, resulting in accumulation of homogentisic acid in the body. (Adapted from reference 8.)

\section{Clinical pResentation}

First clinical signs of AKU are noticed on the locomotor system. The knees are the most commonly affected joints, while changes can also be seen in the spine and other large joints such as hips and shoulders ${ }^{22,23}$. The most commonly affected tissues are intervertebral discs and articular cartilage of joints, which are susceptible to fragmentation. The changes of the spine lead to kyphosis, loss of lumbar lordosis, and height loss ${ }^{15}$. Patients typically have pain and a limited range of motion ${ }^{24}$.

Symptoms may often be similar to those present in inflammatory arthritis (i.e. rheumatoid arthritis, ankylosing spondylitis, gout) or degenerative diseases. When large joints are affected, symptoms are similar to those present in degenerative diseases or rheumatoid arthritis. Patients have joint swelling, synovitis, osteoporosis, and a reduced joint range of motion. Joint swelling is usually a consequence of a reactive hypertrophy of the synovial tissue caused by the ochronotic fragmentation of articular cartilage. If arthrocentesis is performed, small black fragments may be found in the synovial fluid, which is known as "ground pepper sign" ${ }^{2}$. This finding may often be misinterpreted as gout, which is arthritis caused by urate crystal precipitation.

Due to the deposition of HGA in collagen fibers, tendons and ligaments might be thickened. This causes them to be less resistant to mechanical forces, resulting in frequent ruptures caused by minimal trauma ${ }^{2}$. Also, deposition of HGA into collagen fibers in bones causes osteoporosis, which results in an increased risk of fragility fractures. In such cases, a typical finding is a moth-eaten appearance of bones on radiographs ${ }^{24}$. However, spinal fractures do not occur often ${ }^{10}$.

Degenerative changes may affect other systems as well. In the cardiovascular system, changes occur on the mitral and aortal valve as fibrosis and calcification, which leads to their insuf- ficiency. Also, calcification occurs in coronary arteries, causing ischemic changes of the heart. These changes may lead to a need for valve replacement surgery. If the urogenital system is affected, patients have calcinosis of the kidney, urinary bladder, or prostate, which may be identified on radiographic and ultrasound imaging. Also, blue-black pigmentations may be present on the skin, base of the nails, in sclerae (Osler's sign), as well as in cartilage of the nose and ears ${ }^{25}$.

\section{DiAgNOSIS}

Diagnosis of arthropathia ochronotica can be made based on thorough symptoms and past medical history analysis. In childhood, a usual sign is that used diapers are colored black. Despite that fact, in the first year, diagnosis is usually made in only $21 \%$ of patients ${ }^{7,17}$. Diagnosis is most commonly made in the third and fourth decades ${ }^{25}$. The first symptom that patients notice is pain in the joints, although some of them may present with renal colic or cardiovascular symptoms.

After suspecting of arthropathia ochronotica, a further diagnostic imaging is issued ${ }^{21}$. When performing plain radiographs of joints, different stages of degeneration may be noted. Joint space is usually narrowed, and osteophytes, subchondral sclerosis, periarticular calcifications, and degenerative cysts may be present. A typical finding is that degenerative changes are far more advanced than expected for the patient's age. One characteristic of arthropathia ochronotica is that it does not affect small joints of hands and feet, which is a characteristic of rheumatoid arthritis ${ }^{26}$.

Spinal ochronosis may mimic symptoms of ankylosing spondylitis. However, diagnostic imaging helps to distinguish these two entities. In patients suffering from arthropathia ochronotica, a characteristic findings are degeneration and calcification of 
intervertebral discs (wafer-like disc) in the lumbar spine, narrowing of the intervertebral space, and formation of spondylophytes, with no pathological change on facet joints ${ }^{15,24}$. In some patients, a sclerosis of sacroiliac joints may be observed; however, these joints do not show signs of ankylosis. On the other hand, in patients suffering from ankylosing spondylitis, the intervertebral spaces show no signs of narrowing, calcifications are present in the annulus fibrosus, facet joints are ankylosed, and the sacroiliac joints are affected symmetrically ${ }^{26}$.

Moreover, in patients with arthropathia ochronotica, it is possible to observe calcinosis of the kidneys, urinary bladder, or prostate on plain radiographs.

Further diagnostic imaging includes an ultrasound for analyzing calcinosis of the urogenital system, identification of calcification in the cardiovascular system, and for analyzing tendon and ligament continuity. Furthermore, computerized tomography for the analysis of the pathology of the urogenital system and joints, and magnetic resonance imaging for the assessment of the cartilaginous, bony and soft tissue pathology of joints ${ }^{21}$. Moreover, in some cases even PET/CT was used ${ }^{27}$.

AKU is diagnosed based on the increased levels of HGA in the urine $(>4-8 \mathrm{~g} / 24 \mathrm{~h})$ and in the blood $(0.018-0.165 \mathrm{mM}$ vs. $0.014-0.071 \mu \mathrm{M}$ in healthy patients) ${ }^{8,28}$. In contrast to patients who have rheumatoid arthritis or ankylosing spondylitis, blood workup for rheumatoid factors and HLA-B27 are negative in patients suffering from AKU. A biopsy of the affected tissue can further confirm the diagnosis. Synovial biopsy may show typical findings such as inflammation, multiple pigmentation of the connective tissue, reactive osteoclasts and macrophages contain-

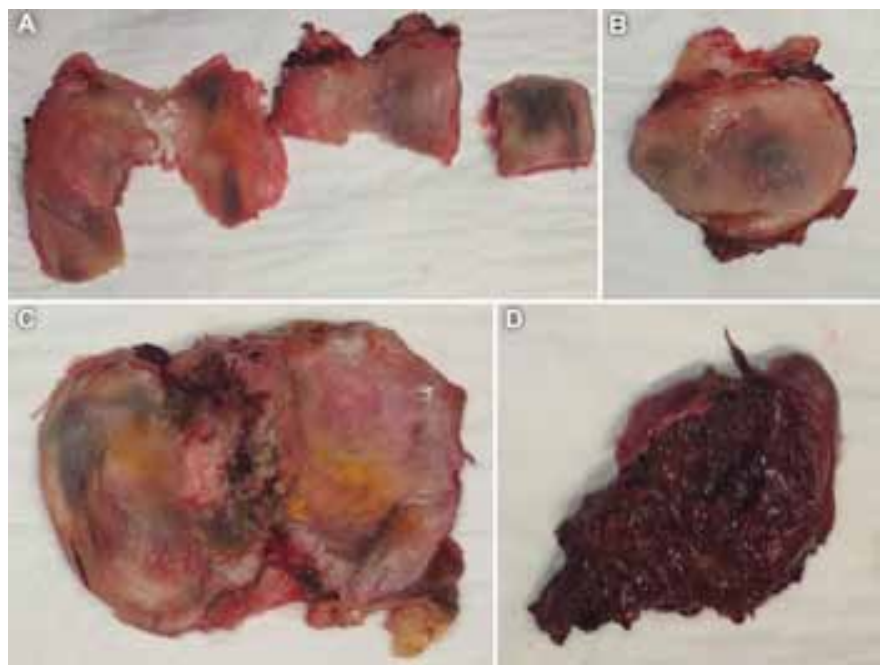

Figure 3. Resected parts during a total knee replacement surgery of a patient who was suffering from arthropathia ochronotica. A) Parts of the femoral condyles and trochlea with visible blue-black pigmentation. B) Parts of the patella with visible blue-black pigmentation. C) Part of the tibia with visible blue-black pigmentation. D) Part of the resected synovial tissue colored dark.
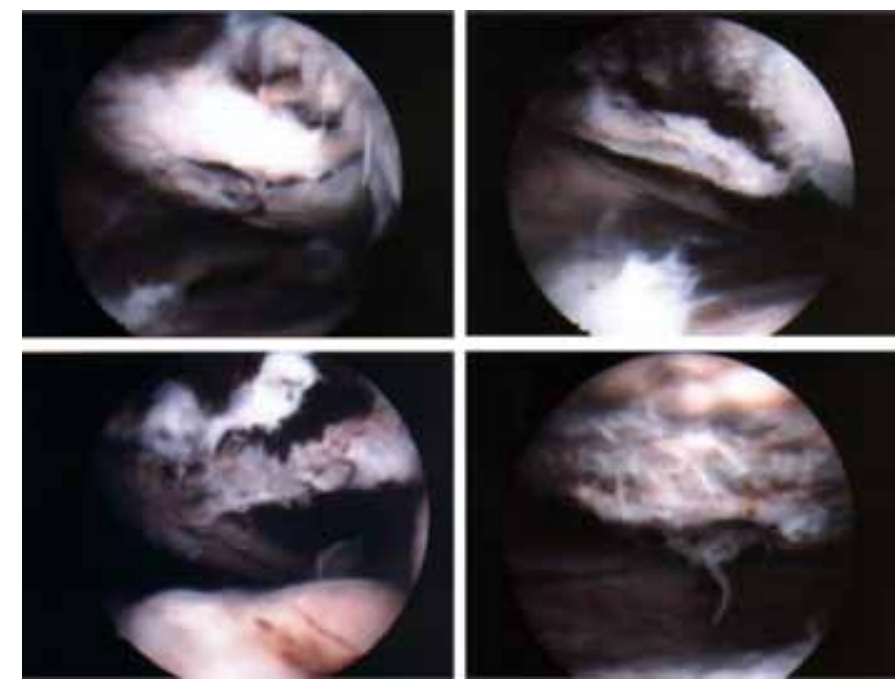

Figure 2. Intraoperative images during an arthroscopic toilette of the knee in a patient suffering from arthropathia ochronotica. Pigmentation of the hyaline cartilage, meniscus, synovial membrane and articular loose bodies are visible in the knee joint.

ing pigmentation ${ }^{2,29}$. Moreover, a database of cartilage histology slides of AKU patients is available online, together with an algorithm helping the researcher to determine whether the slide contains deposits characteristic for $\mathrm{AKU}^{30}$.

Differential diagnosis of AKU includes melanoma, porphyria, porphyria cutanea tarda, paroxysmal nocturnal hemoglobinuria of poisoning with arsenic or silver. An interesting finding is that only $43 \%$ of patients are diagnosed and treated for AKU, while others are mistreated, mostly for melanoma or porphyria ${ }^{10,31}$. Also, exogenic AKU (pseudo-ochronosis) was described ${ }^{10,32,33}$. It is an acquired condition that only occurs as a cutaneous disorder without systemic manifestations ${ }^{33}$. It may be caused by chronic use of medications containing hydroquinone, phenol, resorcinol, mercury, or by use of levodopa and antimalaria drugs ${ }^{10,32}$. The exact cause of pseudo-ochronosis is not known; however, the most accepted theory suggests medications cause competitive inhibition of homogentisate 1,2-dioxygenase in the skin ${ }^{33}$.

\section{TREATMENT}

Currently, there is no causal treatment of arthropathia ochronotica. Symptomatic treatment has the goal of alleviating the patient's pain and improve their functionality and quality of life. Patients are usually on a specific diet, weight regulation is recommended, and they regularly undergo physical therapy. In the early phase of joint degeneration, a conservative approach is used in order to decelerate degeneration. Injections of hyaluronic acid may be applied to affected joints. In patients whose symptoms persist, an arthroscopic toilette of the joint may be performed (i.e. removal of articular loose bodies, synovectomy, meniscectomy, etc.). (Figure 2.) In the late phase of joint degeneration, 
joint replacement surgery may be performed, and it is considered to be a safe and valid treatment option ${ }^{34-37}$. (Figure 3.) Nonsteroidal anti-inflammatory drugs and immunosuppressive therapy may be used, as well as antiresorptive medications for the prevention of osteoporosis and fragility fractures. Some authors recommend a diet with a low consumption of proteins (to avoid intake of phenylalanine and tyrosine) and with a high intake of antioxidants (which prevent oxidation of HGA) such as ascorbic $\operatorname{acid}^{2}$. However, these recommendations haven't been confirmed to be effective by a clinical study.

As a treatment option, some authors suggest the use of a herbicide nitisinone (2-(2-nitro-4-trifluoromethylbenzoyl)-1,3cyclohexanedione), a competitive inhibitor of the 4-hydroxyphenylpyruvate dioxygenase enzyme, which is essential for the creation of HGA. The hypothesis is that the use of nitisinone in childhood prevents the development of complications in adulthood in patients suffering from AKU. Also, if nitisinone is used in adult patients, it should decelerate the progression of the disease and the development of complications. The use of nitisinone reduces the level of HGA in the blood and lowers the urinary excretion up to $70 \%{ }^{10}$. The phase III of SONIA 2 clinical trial testing nitisinone in the treatment of AKU was com- pleted in 2019, and showed promising results in treatment of this rare disease ${ }^{38,39}$. Furthermore, an interesting finding is that liver transplantation may reduce the level of HGA in the blood ${ }^{8}$. Also, as the gene for alkaptonuria is identified, there is a possibility that gene therapy may be developed in the future ${ }^{10,40}$.

\section{CONCLUSION}

In patients suffering from $\mathrm{AKU}$, there is a lack of homogentisate 1,2-dioxygenase enzyme responsible for the oxidation of HGA to maleylacetoacetic acid, consequentially increasing the level of HGA in the body. This accumulation results in a triad of symptoms: 1 . at birth, a change of urine color is present when urine is exposed to air, 2. occurrence of dark pigmentations in connective tissues becomes visible over time, 3. complications of the locomotor, urogenital and cardiovascular systems present gradually. As there is no specific treatment, alleviation of symptoms is the only treatment option. It has the goal of increasing individual functionality and quality of life. As an option for end-stage treatment of arthropathia ochronotica, joint replacement surgery proved to be an effective treatment option. In the future, an enzyme replacement therapy or gene therapy may be developed to treat alkaptonuria successfully. 


\section{LITERATURE:}

1. Di Marco M, De Martinis SE, Truzzi M Vigano R. Polyarticular Ochronotic Arthritis: A Case Report. Case Rep Orthop Res. 2019;2:1-13.

2. Wu K, Bauer E, Myung G, Fang Ma. Musculoskeletal manifestations of alkaptonuria: A case report and literature review. Eur J Rheumatol. 2018;6(2):98-101.

3. Zatkova A, Ranganath L, Kadasi L. Alkaptonuria: Current Perspectives. Appl Clin Genet. 2020;13:37-47.

4. Usher JL, Ascher DB, Pires DE, Milan AM, Blundell TL Ranganath LR. Analysis of HGD Gene Mutations in Patients with Alkaptonuria from the United Kingdom: Identification of Novel Mutations. JIMD Rep. 2014;24:3-11.

5. Aydoğdu S, Cullu E, Ozsoy MH, Sur H. Cementless total knee arthroplasty in ochronotic arthropathy: a case report with a 4-year follow-up. J Arthroplasty. 2000;15(4):539-43.

6. Lal M, Thakur M, Kashyap S. Alkaptonuric ochronosis. Orthopedics. 2014;37(12):e1141-9.

7. Mishra V, Ranganath LR. Pigmented sclera: a diagnostic challenge? Postgr Med J. 2004;80:491-7.

8. Mistry JB, Bukhari M, Taylor AM. Alkaptonuria. Rare Dis. 2013;18(1):e27475.

9. Xu H, Wang J, Chen F, Hong Z, Zhang X, Ji X, et al. Ochronotic arthritis of bilateral knees: a case report. Int J Clin Exp Med. 2015;8(5):8185-9.

10. Fisher AA, Davis MW. Alkaptonuric ochronosis with aortic valve and joint replacements and femoral fracture: a case report and literature review. Clin Med Res. 2004;2(4):209-15.

11. Cunović S, Cunović K, Manestar M. [Alkaptonuria and ochronosis (presentation of a family)]. Lijec Vjesn. 1971;83(9):1031-7.

(in Croatian)

12. Steger CM. Aortic valve ochronosis: a rare manifestation of alkaptonuria. BMJ Case Rep. 2011;2011:bcr0420114119.

13. Thacker M, Garude S, Puri A. Ochronotic arthropathy: arthroscopic findings in the shoulder and the knee. Arthroscopy. 2003;19(8):E14-7.

14. Cobby MJ, Martel W. Some commonly unrecognized manifestations of metabolic arthropathies. Clin Imaging. 1992;16(1):1-14.

15. Gil JA, Wawrzynski J Waryasz GR. Orthopedic Manifestations of Ochronosis: Pathophysiology, Presentation, Diagnosis, and Management. Am J Med. 2016;129(5):536.e1-6.

16. Gómez-Lechón Quirós L, Hidalgo Calleja C, Acosta de la Vega ME, Compán Fernández O, Pastor Navarro S, Montilla Morales C. Family history of ochronotic arthropathy. Rheumatol Int. $2020 \mathrm{Jul}$ 8. doi: 10.1007/s00296-020-04640-2. Epub ahead of print. PMID: 32642830 .

17. Phornphutkul C, Introne WJ, Perry MB, Bernardini I, Murphey MD, Fitzpatrick DL, et al. Natural history of alkaptonuria. N Engl J Med. 2002;347(26):2111-21.

18. Ranganath LR, Milan AM, Hughes AT, Khedr M, Davison

AS, Shweihdi E, et al. Homogentisic acid is not only eliminated by glomerular filtration and tubular secretion but also produced in the kidney in alkaptonuria. J Inherit Metab Dis. 2020;43(4):737-47. 19. Ranganath LR, Norman BP, Gallagher JA. Ochronotic pigmentation is caused by homogentisic acid and is the key event in alkaptonuria leading to the destructive consequences of the disease-A review. J Inherit Metab Dis. 2019;42(5):776-92.

20. Gali VL, Kerkvliet AM, Kusmak JM, Elwood JK. Alkaptonuria: A Case Report With Diagnostic Challenge. S D Med. 2017;70:366-8. 21. Potočki K, Bajramović D, Novosel L. [Rani vs. uznapredovali osteoartritis s aspekta radiologa]. Reumatizam. 2015;62(Suppl. 1):30-5. (in Croatian)

22. La Du BN Jr. Alcaptonuria and ochronotic arthritis. Mol Biol Med. 1991;8(1):31-8.

23. Meschini C, Cauteruccio M, Oliva MS, Sircana G, Vitiello R, Rovere G, et al. Hip and knee replacement in patients with ochronosis: Clinical experience and literature review. Orthop Rev (Pavia). 2020;12(Suppl 1):8687.

24. Murgić L, Grubišić F, Jajić Z. [Neprepoznata ohronoza - prikaz slučaja]. Acta Clin Croat. 2008;47(2):105-9. (in Croatian)

25. Verma SB. Early detection of alkaptonuria. Indian J Dermatol Venereol Leprol. 2005;71:189-91.

26. Balaban B, Taskaynatan M, Yasar E, Tan K, Kalyon T. Ochronotic spondyloarthropathy: spinal involvement resembling ankylosing spondylitis. Clin Rheumatol. 2006;25(4):598-601.

27. Acar E, Bekiş R, Zengin B, Birlik M. Ochronosis Involvement and Extensity With 18F-FDG PET/CT. Clin Nucl Med. 2019;44(5):e360-1.

28. Parlov, A, Petrić, M, Perković D, Martinović Kaliterna D. [Alkaptonurija - prikaz bolesnice]. Liječ Vjesn. 2017;139(7-8):222-4. (in Croatian).

29. Harun M, Hayrettin Y, Serhat M, Cuneyt M, Firat F, Ufuk O. A rare cause of arthropathy: an ochronotic patient with black joints. Int J Surg Case Rep. 2014;5(8):554-7.

30. Rossi A, Giacomini G, Cicaloni V, Galderisi S, Milella MS, Bernini A, et al. AKUImg: A database of cartilage images of Alkaptonuria patients. Comput Biol Med. 2020;122:103863.

31. Nikkels AF, Pierard GE. Medical mystery: the answer. N Engl J Med. 2001;344:1642-3.

32. Kirsch B, Hoesly PM, Jambusaria A, Heckman MG, Diehl NN, Sluzevich JC. Evaluating the Efficacy, Safety, and Tolerability of the Combination of Tazarotene, Azelaic Acid, Tacrolimus, and Zinc Oxide for the Treatment of Melasma: A Pilot Study. J Clin Aesthet Dermatol. 2019;12(5):40-5.

33. Bhattar PA, Zawar VP, Godse KV, Patil SP, Nadkarni NJ, Gautam MM. Exogenous Ochronosis. Indian J Dermatol. 2015;60(6):537-43.

34. Konttinen YT, Hoikka V, Landtman M, Saari H, Santavirta S, Metsärinne $\mathrm{K}$ et al. Ochronosis: a report of a case and a review of literature. Clin Exp Rheumatol. 1989;7(4):435-44.

35. Al-Ajlouni JM, Alisi MS, Yasin MS, Khanfar A, Hamdan M, Halaweh AA, et al. Long-Term Outcomes of the Knee and Hip 
Arthroplasties in Patients with Alkaptonuria. Arthroplast Today. 2020;6(4):689-93.

36. Ilyas I, Kashif S, Algashiri MF, Rabbani SA, Aldakhil SS, AlMohrej OA. Long-term follow-up of bilateral hip and knee arthroplasty secondary to ochronotic arthropathy. Arthroplasty Today. 2020;6(2):214-9.

37. Rajkumar N, Soundarrajan D, Dhanasekararaja P, Rajasekaran S. Clinical and radiological outcomes of total joint arthroplasty in patients with ochronotic arthropathy. Eur J Orthop Surg Traumatol. 2020;30(5):923-9.

38. Davison AS, Strittmatter N, Sutherland H, Hughes AT, Hughes J, Bou-Gharios G, et al. Assessing the effect of nitisinone induced hypertyrosinaemia on monoamine neurotransmitters in brain tissue from a murine model of alkaptonuria using mass spectrometry imaging. Metabolomics. 2019;15(5):68.

39. Ranganath LR, Psarelli EE, Arnoux J-B, Braconi D, Briggs M, Bröijersén A, et al. Efficacy and safety of once-daily nitisinone for patients with alkaptonuria (SONIA 2): an international, multicentre, open-label, randomised controlled trial. Lancet Diabetes Endocrinol. 2020;8(9):762-72.

40. Borman P, Bodur H, Ciliz D. Ochronotic arthropathy. Rheumatol Int. 2002;21(5):205-9. 
